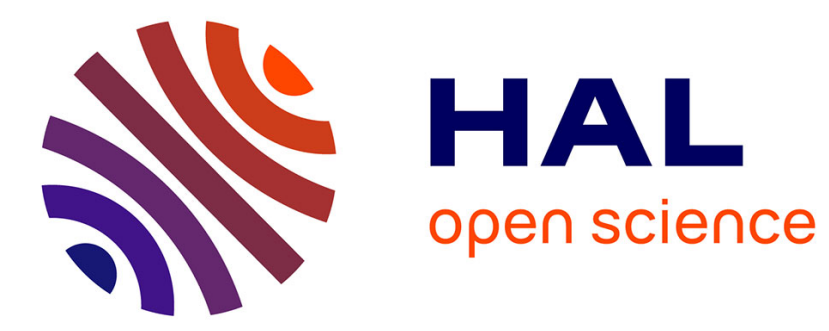

\title{
Therapy for Dominant Inherited Diseases by Allele-Specific RNA Interference: Successes and Pitfalls
}

Delphine Trochet, Bernard Prudhon, Stéphane Vassilopoulos, Marc Bitoun

\section{To cite this version:}

Delphine Trochet, Bernard Prudhon, Stéphane Vassilopoulos, Marc Bitoun. Therapy for Dominant Inherited Diseases by Allele-Specific RNA Interference: Successes and Pitfalls. Current Gene Therapy, 2015, 15 (5), pp.503-510. 10.2174/1566523215666150812115730 . hal-02454502

\section{HAL Id: hal-02454502 https://hal.science/hal-02454502}

Submitted on 24 Jan 2020

HAL is a multi-disciplinary open access archive for the deposit and dissemination of scientific research documents, whether they are published or not. The documents may come from teaching and research institutions in France or abroad, or from public or private research centers.
L'archive ouverte pluridisciplinaire HAL, est destinée au dépôt et à la diffusion de documents scientifiques de niveau recherche, publiés ou non, émanant des établissements d'enseignement et de recherche français ou étrangers, des laboratoires publics ou privés. 
Therapy for dominant inherited diseases by Allele-Specific RNA Interference: Successes and Pitfalls

Delphine Trochet ${ }^{1}$, Bernard Prudhon ${ }^{1}$, Stéphane Vassilopoulos ${ }^{1}$, Marc Bitoun ${ }^{1 *}$

1- Sorbonne Universités, UPMC Univ Paris 06, INSERM UMRS974, CNRS FRE3617, Center for Research in Myology, 47 Boulevard de l'hôpital, 75013 Paris, France

* Correspondence should be addressed to Marc Bitoun, Inserm/UPMC UMR_S974, CNRS FRE3617, Institut de Myologie, Paris, France. e-mail: m.bitoun@institut-myologie.org

Tel: 33 (0) 1.42.16.57.20.

Fax: 33 (0) 1.42.16.57.00.

Running Title: Therapy by allele-specific RNAi 
Abstract: RNA interference (RNAi) is a conserved mechanism for post-transcriptional gene silencing mediated by messenger RNA (mRNA) degradation. RNAi is commonly induced by synthetic siRNA or shRNA which recognizes the targeted mRNA by base pairing and leads to target-mRNA degradation. RNAi may discriminate between two sequences only differing by one nucleotide conferring a high specificity of RNAi for its target mRNA. This property was used to develop a particular therapeutic strategy called "allele-specific-RNA interference" devoted to silence the mutated allele of genes causing dominant inherited diseases without affecting the normal allele. Therapeutic benefit was now demonstrated in cells from patients and animal models, and promising results of the first phase Ib clinical trial using siRNA-based allele-specific therapy were reported in Pachyonychia Congenita, an inherited skin disorder due to dominant mutations in the Keratin 6 gene. Our purpose is to review the successes of this strategy aiming to treat dominant inherited diseases and to highlight the pitfalls to avoid.

Keywords: Allele-specific silencing, Dominant inherited diseases, Pitfalls, RNA interference, Single nucleotide substitution, Gene-based therapy 
RNA interference (RNAi) is a post-transcriptional mechanism of gene silencing first characterized in plants as an anti-virus or anti-transgene defense mechanism [1]. Thereafter, RNAi was shown to induce gene-selective inactivation in a wide variety of eukaryote cells, including mammalian cells [2, 3]. RNAi is classically induced by chemically synthetized small interfering RNA (siRNA) of 19-21 nucleotides with two 3' overhanging nucleotides or by short hairpin RNA (shRNA) synthetized from RNA polymerase III promoters and converted into siRNA by the endogenous cell machinery. The siRNA recognizes the targeted messenger RNA (mRNA) by base pairing of the seed region located from the second to the seventh nucleotide of the siRNA antisense strand referred to as "guide strand". The annealing directs the cleavage of the mRNA after the tenth nucleotide of the siRNA guide strand [4] in the RNA-induced silencing complex (RISC). A fascinating aspect of RNAi stems from its high specificity for the targeted mRNA sequence. This property led to the development of the allelespecific RNAi (AS-RNAi) as a therapeutic strategy for dominant inherited diseases by targeting the mutated allele without affecting the wild type (WT) allele. Proof of concept for a therapeutic use of AS-RNAi was first established in 2002 against dominant mutations of oncogenes or tumor suppressors [5, 6] (Table S1) and, thereafter, rapidly achieved for monogenic dominant inherited diseases [7-10]. During the last decade, therapeutic benefit was also demonstrated in patient-derived cells and animal models, and promising results of the first clinical trial were reported [11]. In this review, we aim at reviewing the state of the art of this strategy applied to treating dominant inherited diseases. The review of the literature also highlights potential limitations and pitfalls to avoid.

\section{AS-RNAi, a versatile strategy for different types of dominant mutations}

The specificity of RNAi-inducing molecules (siRNA and shRNA) led to the development of AS-RNAi for different types of mutations responsible for dominant inherited diseases (Fig. 1). The majority of the AS-RNAi was developed for silencing of mutated alleles differing from the WT alleles by a single nucleotide substitution (Tables 1, 2 and S1), by targeting directly pathogenic missense mutations or disease-associated single nucleotide polymorphisms (da-SNP) in particular cases of triplet repeat diseases. However, AS-RNAi technology was used in several other molecular contexts (Fig. 1 and Table S2). Efficient AS-RNAi was achieved for targeting threenucleotide deletions [7, 12, 13], multiple nucleotide deletions [14] or substitutions [15-21] and diseaseassociated splicing isoforms [22-25]. If the nucleotide repeats responsible for triplet repeat diseases are not considered as suitable targets for AS-siRNA [8] because identical target sequences are present in normal and 
mutated alleles, Li et al. [26] reported effective AS-RNAi against the CAG expansion of the disease-related allele of Ataxin 3 (ATXN3) using siRNA covering the extremity of the expanded region and its flanking sequence. In that case, WT and mutated sequences differ only by the number of repeated motifs while the target sequence of the siRNA is the same in both transcripts. The different repeat sequence lengths may probably induce structural changes allowing allele-specificity in this particular case. More recently, such AS-silencing was achieved using RNA duplexes targeting exclusively the repeated sequence [27-29] but probably by a "miRNA mimicking mechanism" which does not involve mRNA cleavage. Regardless, these results suggest that allelespecific silencing may be envisaged in diseases with nucleotide expansion even in absence of da-SNP. Nevertheless, we will largely focus this review on the AS-RNAi targeting single nucleotide substitutions.

\section{How to develop AS-RNAi targeting single nucleotide substitutions causing dominant inherited diseases}

For targeting single nucleotide substitutions, a perfect AS-siRNA has to achieve effective knock-down of the mutated allele without affecting the normal allele. With this objective, AS-siRNA is designed to fully match the mutated sequence but harbors one mismatch against the WT. The position of the mutated nucleotide in the siRNA, the nature of the mismatch against the WT sequence, and the flanking sequences may influence efficiency and specificity of silencing. Because all these parameters are largely dependent on sequence and structure of a given mRNA, no definitive rules have been established to date for the design of AS-siRNA and development of efficient molecules has relied on empirical testing. Using 19-base-pair siRNA, 19 possible single-mismatched siRNA exist relative to the position of the mutated nucleotide (Fig. 1). Several studies have reported the results from systematic screening for the 19 possible siRNA (Fig. S1) [30-38]. From these studies, central mismatches (from positions 8 to 14) were associated with AS-RNAi with highest specificity at position 10. These data highlight the crucial role of the central region of the siRNA and the fact that AS-RNAi appears more efficient when the siRNA is designed to block the cleavage of the WT allele rather than its annealing. The conclusions from systematic screening may be refined by overall analysis of the 87 single-mismatched siRNA or shRNA reported in the Table S1. The central region proves to be a master region to develop AS-siRNA with the highest specificity reached at position 10 (19 out of 87 ; i.e. $22 \%$ of the reported AS-siRNA), followed by positions 9 and 11 (16\% each). By adding siRNA mismatched at the position 16, these four siRNA (9, 10, 11, and 16) represent $63 \%$ of the already reported efficient molecules. Not only the position but also the nature of the mismatch between siRNA and WT sequences may influence AS-RNAi efficacy with theoretically 
purine:purine (pu:pu) mismatches introducing the largest possible destabilization compared to pyrimidine:pyrimidine (py:py) or purine:pyrimidine (pu:py) mismatches. By definition, in this particular case, the nature of the mismatch is fixed by the mutated nucleotide. It is noteworthy that siRNA with single mismatches at positions $9,10,11$, and 16 have been shown to discriminate mutated and WT alleles whatever the nature of the mismatch (Table $\mathbf{S 1})$.

With the objective to increase allele-specificity, a second mismatch was introduced in the siRNA or shRNA. In that case, the RNAi-inducing molecule harbors one mismatch relative to the mutated sequence but two against the WT. Twelve successful examples of double-mismatched siRNA are indicated in the Table S1 using 19-base pair siRNA including 10 cases in which the first mismatch is located at position 9 or 10 . In these cases, the most efficient positions for the second mismatch are 12,13 and 14 and the majority (6 out of 10) introduces a purine:purine mismatch. Nevertheless, introducing a second mismatch does not always increase AS-RNAi efficiency compared to single-mismatched siRNA [39-43].

Huang et al. analyzed silencing properties of siRNAs on 230 reporter constructs and confirmed that some positions are more sensitive than others to target a given mismatch [44]. This study and the successful examples now available for 31 distinct mRNA (Table S1) suggest a two-step strategy in order to develop AS-RNAi. Single mismatched siRNA at positions $9,10,11$, and 16 should be privileged as a first screening strategy whatever the nature of the mismatch. In case of low allele-specificity, a second purine:purine mismatch may be introduced at positions 12,13 , or 14 in addition to the first mismatch at positions 9 , and 10 . These 10 different siRNA sequences (out of the 667 possible single and double-mismatched siRNA) may facilitate the development of ASRNAi as they represent $65 \%$ of the efficient AS-siRNA already reported. This strategy may be associated with the recently developed formulas for calculating allele-discrimination [45] in order to optimize determination of allele-specific siRNA.

\section{Proof of concept of AS-RNAi in patient-derived cells and animal models}

Phenotype reversion in patient-derived cells and/or animal models is a crucial step for preclinical development. This was achieved in vitro for numerous disease-related genes mainly in patient-derived fibroblasts (Table 1). Interestingly, induced pluripotent stem cells (iPSCs) derived towards neuronal cells as an Amyotrophic lateral sclerosis model [42] or toward cardiomyocytes as a Long QT syndrome model [46] were recently used to study AS-RNAi in functionally relevant disease models. Validation of AS-RNAi in pertinent 
disease-related cells appears particularly important in absence of primary cultures from the affected tissue and iPSC represent probably a model of choice.

In vivo AS-RNAi was reported for the first time in 2003 by Ding and collaborators after co-injection of WT and mutated SOD1 constructs with shRNA in mice [10]. Beyond the first in vivo proof of concept, this pioneer study demonstrated the rapid silencing of the mutated allele evidenced 24 hours post-transfection. Afterwards, different types of animal models (transgenic mice or vector-mediated overexpression of mutated transcripts) were developed in order to study the feasibility of AS-RNAi in vivo (Table 2). These models confirmed the rapid down-regulation of the mutated alleles [31, 34] and highlighted several important features of in vivo ASsilencing. First, early treatment in pre-symptomatic animals is able to prevent the appearance and/or the progression of the disease [21, 47-50]. Second, rescue of phenotype is also possible when treatment is started in symptomatic mice [51]. Third, the therapeutic effect is rapid as evidenced after 2-4 weeks of treatment $[50,51]$ without evident long-term toxicity [21]. Fourth, a low therapeutic threshold was demonstrated as incomplete reduction of the mutated allele was sufficient for therapeutic benefit [48, 49]. The last point may be of importance for particular mutations for which highly efficient AS-siRNA could not be easily designed.

In addition to these helpful experimental in vivo models, therapeutic potential of AS-RNAi was also investigated in Knock-in mouse models expressing disease-causing mutations in the endogenous mouse genes to recapitulate more closely the human heterozygous conditions. This was achieved in a mouse model of the Apert syndrome expressing a Fgfr2 (Fibroblast growth factor receptor type 2) mutation [20], in two models of neuromuscular disorders due to Ryrl (Ryanodine receptor type 1) mutations [19], and in one model of Hypertrophic cardiomyopathy due to a Myh6 (Myosin heavy chain 6) mutation [52]. Among these, the Knockin-Myh6 mice represent the only case of mutation due to a single nucleotide substitution (in the three other models, the mutations come from double or triple substitutions). AS-RNAi in these knock-in models confirmed the safety, the rapidity, and efficacy of this therapeutic strategy to rescue or prevent the phenotype. A low therapeutic threshold was evidenced in the Myh6 model as a reduction of $28.5 \%$ of the mutated allele benefited the mice whereas a reduction of $50 \%$ led to a partial rescue in one Ryrl model. In addition, AS-RNAi only delayed the cardiac phenotype but was unable to rescue an established cardiomyopathy in the Myh6 mice and a dissipation of protective effect over time was noticed [52]. These findings that may be gene- and/or diseasespecific reveal the importance of functional validation in pertinent Knock-in mouse models for each targeted dominant disease. 


\section{Clinical trials in humans}

Pachyonychia congenita (PC) is a highly disabling autosomal dominant skin disorder due to mutations in the Keratin 6 gene $(K R T 6 A)$. The clinical manifestations of PC include painful plantar calluses which have been targeted successfully by AS-RNAi in a clinical trial reported in 2010 [11]. Treatment consisted of 17 weeks of intra-callus injections performed twice-weekly with dose escalation from $0.1 \mathrm{mg}$ to $17 \mathrm{mg}$ of siRNA against the mutated Krt6a mRNA. Clinical improvement with callus regression was noticed from 10 weeks after the first injection and was maintained during a relatively long period of 14 weeks, i.e. 7 weeks after the last injection. Despite the spatially and temporally limited effects, which highlight the importance of the delivery method for future trials, this first report of AS-RNAi in human are promising for PC and other dominant inherited diseases.

\section{Pitfall and limitation}

Several specific aspects of the AS-RNAi technology, which may limit development of future effective treatments for dominant inherited diseases, require consideration.

1) Probably the most important point is that the expected result of this approach is to retain only $50 \%$ expression from the spared WT allele of the gene of interest. Consequently, absence of haploinsufficiency needs to be clearly established. In this context, in vitro knock-down studies, investigation of heterozygous knock-out animal models when available and analysis of the spectrum of gene mutations and genotype-phenotype correlation in patients are indispensable.

2) Another serious limitation is the restriction in the choice for the targeted sequence in the region of the mRNA harboring the mutation. This may limit efficiency of RNAi as all the regions of a given mRNA are not similarly sensitive to RNAi and may restrict efficacy and allele-specific silencing. In other words, AS-RNAi will not be possible in all cases. However, this problem may be overcome if targetable SNP is present on the mutated allele. 3) It is important to take into account the possibility that the AS-RNAi molecule can inhibit the translation of the WT allele whereas the quantified WT mRNA level remains unchanged [15]. This may be due to a "microRNA effect" affecting the translation as already described for mismatched siRNA [53]. Consequently, allele-specific properties should not be established exclusively by measuring the mRNA expression level but need to be combined to protein expression and protein activity when possible. 
4) A loss of allele-specificity with increased dose of RNAi-inducing molecule [54] or an arrest of protective effect over time may appear [52]. This highlights the importance of the choice of the vector, mode of delivery and tight control of the delivered amount of future therapeutic molecules in vivo. In this context, miRNA-based hairpins have been used in order to express AS-RNAi-inducing molecules [25, 39]. This approach may offer an attractive alternative for in vivo tissue-specific expression compared to siRNA or shRNA and to avoid potential toxicity of shRNA expression in vivo $[55,56]$.

5) In order to facilitate the screening for AS-siRNA in vitro, artificial assay systems with reporter genes have been developed. Using this screening procedure, siRNA maintaining their allele specificity against the bona fide mRNA target were identified $[15,30,33,36,57,58]$. However, significant discrepancies have been shown comparing reporter systems and full-length mRNA or even between two different reporter systems [34-37, 39, 43, 59]. Consequently, screening for AS-siRNA on the full-length natural target (endogenous or overexpressed) should be privileged.

6) The best AS-siRNA sequences identified in vitro are often incorporated into plasmids or viral vectors to be expressed in vivo as shRNA. The shRNAs are known to retain the efficacy and allele specificity of the original siRNA $[8,10]$ but some divergences may exist between siRNA and the corresponding shRNA $[9,12,18]$. Indeed, shRNA are processed by the endogenous Dicer RNAse to generate siRNA. Given that Dicer cleavage site in the shRNA loop is difficult to predict that may introduce one or two-nucleotide differences between the expected and the produced siRNA. Consequently, even if several examples showed that AS-siRNA and ASshRNA are similarly efficient, it would be important to validate shRNA constructs in vitro before starting in vivo studies in animals.

7) By definition, the AS-RNAi strategy is a mutation-specific approach. This may be interesting for mutation hot spots concentrated in a reduced number of nucleotides allowing development of common molecular tools for a large cohort of patients. In contrast, this may require personalized therapy by developing specific tools for mutations affecting few patients.

8) Another limitation comes from the study of Jiang and collaborators [52] which stress the necessity to start treatment at a pre-symptomatic stage. In such cases, AS-RNAi could be limited to familial forms of diseases receiving an early genetic diagnosis. Development of preclinical studies in knock-in animal models appears crucial to determine the optimal timing of treatment.

9) Interferon response classically attributed to long double-stranded RNA has not been reported in AS-RNAi to date. Nevertheless, some siRNA [60] and shRNA [61] have been shown to induce this response. Consequently, 
monitoring a possible interferon response should be included, especially for in vivo studies, to avoid misinterpretation of treatment efficacy.

\section{Concluding remarks}

Despite of the possible limitations indicated above, the AS-RNAi technology emerged during the last decade as a powerful strategy for dominant inherited diseases. However, some aspects still need to be resolved especially those concerning in vivo delivery. Similar to all the siRNA-based therapeutics, using the best vector for delivering the optimal dose will probably be the key bottleneck when systemic delivery is required for widespread dissemination or in contrast for limited expression in one affected tissue. Also, the long-term consequences of chronic stimulation of the RNAi pathway (potential toxicity or immunological side effects as reviewed in [62]) as well as off-target effects need to be carefully investigated. Continuous improvements to overcome these limitations and increase efficacy of RNAi-based therapeutics, including chemical modifications, are occurring and will benefit the AS-RNAi strategy. Furthermore, development of preclinical testing in animal models of dominant inherited diseases are now crucial in order to deepen the specificities of the AS-RNAi approach in vivo such as long-term maintenance of allele-specificity. Nevertheless, the proof of concept for ASRNAi therapy now available for numerous dominant inherited diseases strongly suggests that the promising result of the first clinical trial for Pachyonychia Congenita paves the way for future successful clinical trials. 


\section{Conflict of interest}

There is no conflict of interest to disclose.

\section{Acknowledgements}

This work was supported by the Institut National de la Santé et de la Recherche Médicale (INSERM), the Association Institut de Myologie (AIM), the Université Pierre et Marie Curie-Paris6 (UPMC) and the Centre National de la Recherche Scientifique (CNRS). DT is recipient of an AIM fellowship. All authors wrote the review. 


\section{References}

[1] Fire A, Xu S, Montgomery MK, Kostas SA, Driver SE, Mello CC. Potent and specific genetic interference by double-stranded RNA in Caenorhabditis elegans. Nature. 1998;391(6669):806-11.

[2] Elbashir SM, Harborth J, Lendeckel W, Yalcin A, Weber K, Tuschl T. Duplexes of 21-nucleotide RNAs mediate RNA interference in cultured mammalian cells. Nature. 2001;411(6836):494-8.

[3] Caplen NJ, Parrish S, Imani F, Fire A, Morgan RA. Specific inhibition of gene expression by small double-stranded RNAs in invertebrate and vertebrate systems. Proc Natl Acad Sci U S A. 2001;98(17):9742-7.

[4] Elbashir SM, Martinez J, Patkaniowska A, Lendeckel W, Tuschl T. Functional anatomy of siRNAs for mediating efficient RNAi in Drosophila melanogaster embryo lysate. EMBO J. 2001;20(23):6877-88.

[5] Martinez LA, Naguibneva I, Lehrmann H, Vervisch A, Tchenio T, Lozano G, et al. Synthetic small inhibiting RNAs: efficient tools to inactivate oncogenic mutations and restore p53 pathways. Proc Natl Acad Sci U S A. 2002;99(23):14849-54.

[6] Brummelkamp TR, Bernards R, Agami R. Stable suppression of tumorigenicity by virus-mediated RNA interference. Cancer cell. 2002;2(3):243-7.

[7] Gonzalez-Alegre P, Miller VM, Davidson BL, Paulson HL. Toward therapy for DYT1 dystonia: allelespecific silencing of mutant TorsinA. Ann Neurol. 2003;53(6):781-7.

[8] Miller VM, Xia H, Marrs GL, Gouvion CM, Lee G, Davidson BL, et al. Allele-specific silencing of dominant disease genes. Proc Natl Acad Sci U S A. 2003;100(12):7195-200.

[9] Abdelgany A, Wood M, Beeson D. Allele-specific silencing of a pathogenic mutant acetylcholine receptor subunit by RNA interference. Hum Mol Genet. 2003;12(20):2637-44.

[10] Ding H, Schwarz DS, Keene A, Affar el B, Fenton L, Xia X, et al. Selective silencing by RNAi of a dominant allele that causes amyotrophic lateral sclerosis. Aging cell. 2003;2(4):209-17.

[11] Leachman SA, Hickerson RP, Schwartz ME, Bullough EE, Hutcherson SL, Boucher KM, et al. First-inhuman mutation-targeted siRNA phase Ib trial of an inherited skin disorder. Mol Ther. 2010;18(2):442-6.

[12] Gonzalez-Alegre P, Bode N, Davidson BL, Paulson HL. Silencing primary dystonia: lentiviral-mediated RNA interference therapy for DYT1 dystonia. J Neurosci. 2005;25(45):10502-9.

[13] Zhang Y, Engelman J, Friedlander RM. Allele-specific silencing of mutant Huntington's disease gene. J Neurochem. 2009;108(1):82-90. 
[14] Takahashi M, Chiyo T, Okada T, Hohjoh H. Specific inhibition of tumor cells by oncogenic EGFR specific silencing by RNA interference. PLoS One. 2013;8(8):e73214.

[15] Ohnishi Y, Tokunaga K, Kaneko K, Hohjoh H. Assessment of allele-specific gene silencing by RNA interference with mutant and wild-type reporter alleles. J RNAi Gene Silencing. 2006;2(1):154-60.

[16] Feng X, Zhao P, He Y, Zuo Z. Allele-specific silencing of Alzheimer's disease genes: the amyloid precursor protein genes with Swedish or London mutations. Gene. 2006;371(1):68-74.

[17] Miller VM, Gouvion CM, Davidson BL, Paulson HL. Targeting Alzheimer's disease genes with RNA interference: an efficient strategy for silencing mutant alleles. Nucleic Acids Res. 2004;32(2):661-8.

[18] Rousseau J, Gioia R, Layrolle P, Lieubeau B, Heymann D, Rossi A, et al. Allele-specific Col1a1 silencing reduces mutant collagen in fibroblasts from Brtl mouse, a model for classical osteogenesis imperfecta. Eur J Hum Genet. 2014;22(5):667-74.

[19] Loy RE, Lueck JD, Mostajo-Radji MA, Carrell EM, Dirksen RT. Allele-specific gene silencing in two mouse models of autosomal dominant skeletal myopathy. PLoS One. 2012;7(11):e49757.

[20] Shukla V, Coumoul X, Wang RH, Kim HS, Deng CX. RNA interference and inhibition of MEK-ERK signaling prevent abnormal skeletal phenotypes in a mouse model of craniosynostosis. Nat Genet. 2007;39(9):1145-50.

[21] Rodriguez-Lebron E, Gouvion CM, Moore SA, Davidson BL, Paulson HL. Allele-specific RNAi mitigates phenotypic progression in a transgenic model of Alzheimer's disease. Mol Ther. 2009;17(9):1563-73.

[22] Fan QW, Weiss WA. RNA interference against a glioma-derived allele of EGFR induces blockade at G2M. Oncogene. 2005;24(5):829-37.

[23] Pendaries V, Gasc G, Titeux M, Tonasso L, Mejia JE, Hovnanian A. siRNA-mediated allele-specific inhibition of mutant type VII collagen in dominant dystrophic epidermolysis bullosa. J Invest Dermatol. 2012;132(6):1741-3.

[24] Bolduc V, Zou Y, Ko D, Bonnemann CG. siRNA-mediated Allele-specific Silencing of a COL6A3 Mutation in a Cellular Model of Dominant Ullrich Muscular Dystrophy. Molecular therapy Nucleic acids. 2014;3:e147.

[25] Tsou WL, Soong BW, Paulson HL, Rodriguez-Lebron E. Splice isoform-specific suppression of the Cav2.1 variant underlying spinocerebellar ataxia type 6. Neurobiol Dis. 2011;43(3):533-42.

[26] Li Y, Yokota T, Matsumura R, Taira K, Mizusawa H. Sequence-dependent and independent inhibition specific for mutant ataxin-3 by small interfering RNA. Ann Neurol. 2004;56(1):124-9. 

targeting expanded CAG repeats. Nucleic Acids Res. 2011;39(13):5578-85.

[28] Hu J, Liu J, Corey DR. Allele-selective inhibition of huntingtin expression by switching to an miRNAlike RNAi mechanism. Chem Biol. 2010;17(11):1183-8.

[29] Hu J, Gagnon KT, Liu J, Watts JK, Syeda-Nawaz J, Bennett CF, et al. Allele-selective inhibition of ataxin-3 (ATX3) expression by antisense oligomers and duplex RNAs. Biol Chem. 2011;392(4):315-25.

[30] Schwarz DS, Ding H, Kennington L, Moore JT, Schelter J, Burchard J, et al. Designing siRNA that distinguish between genes that differ by a single nucleotide. PLoS Genet. 2006;2(9):e140.

[31] Hickerson RP, Smith FJ, Reeves RE, Contag CH, Leake D, Leachman SA, et al. Single-nucleotidespecific siRNA targeting in a dominant-negative skin model. J Invest Dermatol. 2008;128(3):594-605.

[32] Sierant M, Paduszynska A, Kazmierczak-Baranska J, Nacmias B, Sorbi S, Bagnoli S, et al. Specific Silencing of L392V PSEN1 Mutant Allele by RNA Interference. Int J Alzheimers Dis. 2011;2011:809218.

[33] Liao H, Irvine AD, Macewen CJ, Weed KH, Porter L, Corden LD, et al. Development of allele-specific therapeutic siRNA in Meesmann epithelial corneal dystrophy. PLoS One. 2011;6(12):e28582.

[34] Leslie Pedrioli DM, Fu DJ, Gonzalez-Gonzalez E, Contag CH, Kaspar RL, Smith FJ, et al. Generic and personalized RNAi-based therapeutics for a dominant-negative epidermal fragility disorder. J Invest Dermatol. 2012;132(6):1627-35.

[35] Muller GA, Hansen U, Xu Z, Griswold B, Talan MI, McDonnell NB, et al. Allele-specific siRNA knockdown as a personalized treatment strategy for vascular Ehlers-Danlos syndrome in human fibroblasts. FASEB J. 2012;26(2):668-77.

[36] Atkinson SD, McGilligan VE, Liao H, Szeverenyi I, Smith FJ, Moore CB, et al. Development of allelespecific therapeutic siRNA for keratin 5 mutations in epidermolysis bullosa simplex. J Invest Dermatol. 2011;131(10):2079-86.

[37] Allen EH, Atkinson SD, Liao H, Moore JE, Leslie Pedrioli DM, Smith FJ, et al. Allele-specific siRNA silencing for the common keratin 12 founder mutation in Meesmann epithelial corneal dystrophy. Invest Ophthal Vis Sci. 2013;54(1):494-502.

[38] Courtney DG, Atkinson SD, Moore JE, Maurizi E, Serafini C, Pellegrini G, et al. Development of allele-specific gene-silencing siRNAs for TGFBI Arg124Cys in lattice corneal dystrophy type I. Invest Ophthal Vis Sci. 2014;55(2):977-85. 

hairpins for mutation-specific silencing of ataxin-7 and correction of a SCA7 phenotype. PLoS One. 2009;4(9):e7232.

[40] Sibley CR, Wood MJ. Identification of allele-specific RNAi effectors targeting genetic forms of Parkinson's disease. PLoS One. 2011;6(10):e26194.

[41] Sapru MK, Yates JW, Hogan S, Jiang L, Halter J, Bohn MC. Silencing of human alpha-synuclein in vitro and in rat brain using lentiviral-mediated RNAi. Exp Neurol. 2006;198(2):382-90.

[42] Nishimura AL, Shum C, Scotter EL, Abdelgany A, Sardone V, Wright J, et al. Allele-specific knockdown of ALS-associated mutant TDP-43 in neural stem cells derived from induced pluripotent stem cells. PLoS One. 2014;9(3):e91269.

[43] Noguchi S, Ogawa M, Kawahara G, Malicdan MC, Nishino I. Allele-specific Gene Silencing of Mutant mRNA Restores Cellular Function in Ullrich Congenital Muscular Dystrophy Fibroblasts. Mol Ther Nucleic Acids. 2014;3:e171.

[44] Huang H, Qiao R, Zhao D, Zhang T, Li Y, Yi F, et al. Profiling of mismatch discrimination in RNAi enabled rational design of allele-specific siRNAs. Nucleic Acids Res. 2009;37(22):7560-9.

[45] Takahashi M, Hohjoh H. A novel measurement of allele discrimination for assessment of allele-specific silencing by RNA interference. Mol Biol Rep. 2014;41(11):7115-20.

[46] Matsa E, Dixon JE, Medway C, Georgiou O, Patel MJ, Morgan K, et al. Allele-specific RNA interference rescues the long-QT syndrome phenotype in human-induced pluripotency stem cell cardiomyocytes. Eur Heart J. 2013;35:1078-87.

[47] Alves S, Nascimento-Ferreira I, Auregan G, Hassig R, Dufour N, Brouillet E, et al. Allele-specific RNA silencing of mutant ataxin-3 mediates neuroprotection in a rat model of Machado-Joseph disease. PLoS One. 2008;3(10):e3341.

[48] Drouet V, Ruiz M, Zala D, Feyeux M, Auregan G, Cambon K, et al. Allele-specific silencing of mutant huntingtin in rodent brain and human stem cells. PLoS One. 2014;9(6):e99341.

[49] Xia X, Zhou H, Huang Y, Xu Z. Allele-specific RNAi selectively silences mutant SOD1 and achieves significant therapeutic benefit in vivo. Neurobiol Dis. 2006;23(3):578-86.

[50] Nobrega C, Nascimento-Ferreira I, Onofre I, Albuquerque D, Deglon N, Pereira de Almeida L. RNA interference mitigates motor and neuropathological deficits in a cerebellar mouse model of machado-joseph disease. PLoS One. 2014;9(8):e100086. 
[51] Nobrega C, Nascimento-Ferreira I, Onofre I, Albuquerque D, Hirai H, Deglon N, et al. Silencing mutant ataxin-3 rescues motor deficits and neuropathology in Machado-Joseph disease transgenic mice. PLoS One. 2013;8(1):e52396.

[52] Jiang J, Wakimoto H, Seidman JG, Seidman CE. Allele-Specific Silencing of Mutant Myh6 Transcripts in Mice Suppresses Hypertrophic Cardiomyopathy. Science. 2013;342(6154):111-4.

[53] Saxena S, Jonsson ZO, Dutta A. Small RNAs with imperfect match to endogenous mRNA repress translation. Implications for off-target activity of small inhibitory RNA in mammalian cells. J Biol Chem. $2003 ; 278(45): 44312-9$.

[54] Scholefield J, Watson L, Smith D, Greenberg J, Wood MJ. Allele-specific silencing of mutant Ataxin-7 in SCA7 patient-derived fibroblasts. Eur J Hum Genet. 2014.

[55] McBride JL, Boudreau RL, Harper SQ, Staber PD, Monteys AM, Martins I, et al. Artificial miRNAs mitigate shRNA-mediated toxicity in the brain: implications for the therapeutic development of RNAi. Proc Natl Acad Sci U S A. 2008;105(15):5868-73.

[56] Grimm D, Streetz KL, Jopling CL, Storm TA, Pandey K, Davis CR, et al. Fatality in mice due to oversaturation of cellular microRNA/short hairpin RNA pathways. Nature. 2006;441(7092):537-41.

[57] Dykxhoorn DM, Schlehuber LD, London IM, Lieberman J. Determinants of specific RNA interferencemediated silencing of human beta-globin alleles differing by a single nucleotide polymorphism. Proc Natl Acad Sci U S A. 2006;103(15):5953-8.

[58] Lombardi MS, Jaspers L, Spronkmans C, Gellera C, Taroni F, Di Maria E, et al. A majority of Huntington's disease patients may be treatable by individualized allele-specific RNA interference. Exp Neurol. $2009 ; 217(2): 312-9$.

[59] de Ynigo-Mojado L, Martin-Ruiz I, Sutherland JD. Efficient allele-specific targeting of LRRK2 R1441 mutations mediated by RNAi. PLoS One. 2011;6(6):e21352.

[60] Hornung V, Guenthner-Biller M, Bourquin C, Ablasser A, Schlee M, Uematsu S, et al. Sequencespecific potent induction of IFN-alpha by short interfering RNA in plasmacytoid dendritic cells through TLR7. Nat Med. 2005;11(3):263-70.

[61] Bridge AJ, Pebernard S, Ducraux A, Nicoulaz AL, Iggo R. Induction of an interferon response by RNAi vectors in mammalian cells. Nat Genet. 2003;34(3):263-4.

[62] Olejniczak M, Polak K, Galka-Marciniak P, Krzyzosiak WJ. Recent advances in understanding of the immunological off-target effects of siRNA. Curr Gene Ther. 2011;11(6):532-43. 
[63] Kaplan J, Kaplan FS, Shore EM. Restoration of normal BMP signaling levels and osteogenic differentiation in FOP mesenchymal progenitor cells by mutant allele-specific targeting. Gene Ther. 2012;19(7):786-90.

[64] Takahashi M, Katagiri T, Furuya H, Hohjoh H. Disease-causing allele-specific silencing against the ALK2 mutants, R206H and G356D, in fibrodysplasia ossificans progressiva. Gene Ther. 2012;19(7):781-5.

[65] Fiszer A, Olejniczak M, Switonski PM, Wroblewska JP, Wisniewska-Kruk J, Mykowska A, et al. An evaluation of oligonucleotide-based therapeutic strategies for polyQ diseases. BMC Mol Biol. 2012;13:6.

[66] Lindahl K, Rubin CJ, Kindmark A, Ljunggren O. Allele dependent silencing of COL1A2 using small interfering RNAs. International journal of medical sciences. 2008;5(6):361-5.

[67] Klootwijk RD, Savelkoul PJ, Ciccone C, Manoli I, Caplen NJ, Krasnewich DM, et al. Allele-specific silencing of the dominant disease allele in sialuria by RNA interference. FASEB J. 2008;22(11):3846-52.

[68] van Bilsen PH, Jaspers L, Lombardi MS, Odekerken JC, Burright EN, Kaemmerer WF. Identification and allele-specific silencing of the mutant huntingtin allele in Huntington's disease patient-derived fibroblasts. Hum Gene Ther. 2008;19(7):710-9.

[69] Takahashi M, Watanabe S, Murata M, Furuya H, Kanazawa I, Wada K, et al. Tailor-made RNAi knockdown against triplet repeat disease-causing alleles. Proc Natl Acad Sci U S A. 2010;107(50):21731-6.

[70] Courtney DG, Atkinson SD, Allen EH, Moore JE, Walsh CP, Pedrioli DM, et al. siRNA silencing of the mutant keratin 12 allele in corneal limbal epithelial cells grown from patients with Meesmann's epithelial corneal dystrophy. Invest Ophthal Vis Sci. 2014;55(5):3352-60.

[71] Towne C, Raoul C, Schneider BL, Aebischer P. Systemic AAV6 delivery mediating RNA interference against SOD1: neuromuscular transduction does not alter disease progression in fALS mice. Mol Ther. 2008;16(6):1018-25.

[72] Teng X, Xu WZ, Hao ML, Fang Y, Zhao YX, Chen SJ, et al. Differential inhibition of lamivudineresistant hepatitis B virus by allele-specific RNAi. J Virol Methods. 2010;168(1-2):6-12.

[73] Pfister EL, Kennington L, Straubhaar J, Wagh S, Liu W, DiFiglia M, et al. Five siRNAs targeting three SNPs may provide therapy for three-quarters of Huntington's disease patients. Curr Biol. 2009;19(9):774-8.

[74] Ohnishi Y, Tamura Y, Yoshida M, Tokunaga K, Hohjoh H. Enhancement of allele discrimination by introduction of nucleotide mismatches into siRNA in allele-specific gene silencing by RNAi. PLoS One. 2008;3(5):e2248. 
[75] Maxwell MM, Pasinelli P, Kazantsev AG, Brown RH, Jr. RNA interference-mediated silencing of mutant superoxide dismutase rescues cyclosporin A-induced death in cultured neuroblastoma cells. Proc Natl Acad Sci U S A. 2004;101(9):3178-83.

[76] Kurosawa T, Igarashi S, Nishizawa M, Onodera O. Selective silencing of a mutant transthyretin allele by small interfering RNAs. Biochem Biophys Res Commun. 2005;337(3):1012-8. 
Figure 1: AS-RNAi targetable mutations. For targeting a single nucleotide substitution, the 19 possible siRNAs are indicated relative to the position of the mutated nucleotide. This specific nucleotide determines the position of the mismatch between the siRNA and the WT mRNA. P10 indicates the siRNA mismatched at position 10. nt: nucleotide. Specific nucleotides of the mutated mRNA are indicated in blue.

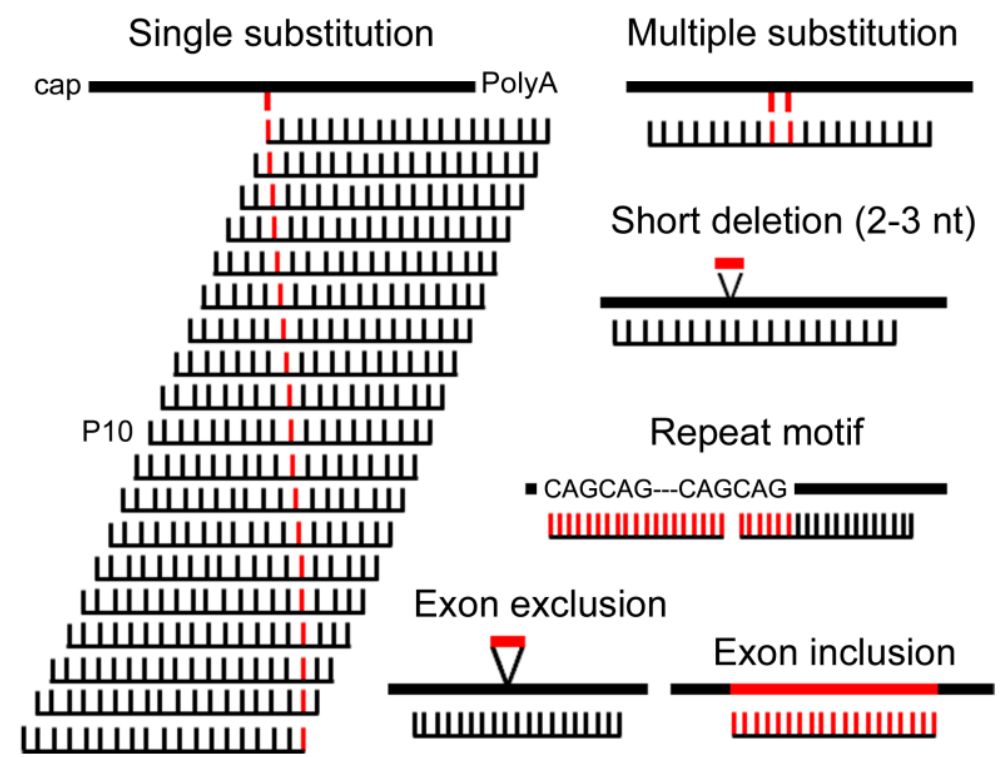


Table 1: Single nucleotide substitutions targeted by Allele-specific RNAi in patient-derived cells

\begin{tabular}{|c|c|c|c|c|c|}
\hline Gene & Disease & $\begin{array}{c}\text { Targeted } \\
\text { change }\end{array}$ & Model & $\begin{array}{c}\text { Phenotype } \\
\text { reversion }\end{array}$ & References \\
\hline ACVR1 & FOP & p.R206H & Primary MSC & yes & {$[63]$} \\
\hline ACVR1 & FOP & $\begin{array}{c}\text { p.R206H } \\
\text { p.G356D }\end{array}$ & $\begin{array}{c}\text { Lymphoblastoid } \\
\text { cells }\end{array}$ & yes & {$[64]$} \\
\hline ATXN1 & SCA1 & da-SNP & Fibroblast & - & {$[65]$} \\
\hline ATXN3 & SCA3 & da-SNP & Fibroblast & - & {$[65]$} \\
\hline ATXN7 & SCA7 & da-SNP & Fibroblast & yes & {$[54]$} \\
\hline COL1A2 & OI & da-SNP & $\begin{array}{c}\text { Bone-derived } \\
\text { cells }\end{array}$ & - & {$[66]$} \\
\hline COL3A1 & vEDS & p.G252V & Fibroblast & yes & {$[35]$} \\
\hline COL6A1 & UCMD & p.G284R & Fibroblast & yes & {$[43]$} \\
\hline GNE & Sialuria & p.R266Q & Fibroblast & yes & {$[67]$} \\
\hline HTT & HD & da-SNP & Fibroblast & - & {$[68]$} \\
\hline HTT & HD & da-SNP & Fibroblast & - & {$[58]$} \\
\hline HTT & HD & da-SNP & $\begin{array}{c}\text { Lymphoblastoid } \\
\text { cells }\end{array}$ & - & {$[69]$} \\
\hline HTT & HD & da-SNP & Fibroblast & - & {$[65]$} \\
\hline HTT & HD & da-SNP & Neural stem cells & yes & {$[48]$} \\
\hline KCNH2 & LQT2 & p.A561T & $\begin{array}{c}\text { iPSC-derived } \\
\text { cardiomyocyte }\end{array}$ & yes & {$[46]$} \\
\hline KRT12 & MECD & p.L132P & Corneal epithelial & - & {$[70]$} \\
\hline PSEN1 & AD & p.L392V & Fibroblast & yes & {$[32]$} \\
\hline TARDBP & ALS & p.M337V & $\begin{array}{c}\text { iPSC-derived } \\
\text { neural stem cell }\end{array}$ & - & {$[42]$} \\
\hline TGFBI & LCDI & p.R124C & $\begin{array}{c}\text { Corneal epithelial } \\
\text { cells }\end{array}$ & - & {$[38]$} \\
\hline
\end{tabular}

GNE: UDP-N-acetylglucosamine 2-epimerase/N-acetylmannosamine kinase, HTT: Huntingtin, HD: Huntington's disease, ATXN1: Ataxin 1, ATXN3: Ataxin 3, ATXN7: Ataxin 7, SCA1: Spinocerebellar ataxia 1, SCA3: Spinocerebellar ataxia 3, SCA7: Spinocerebellar ataxia 7, TARDBP: TAR-DNA Binding protein (TDB43), ALS: Amyotrophic lateral sclerosis, PSEN1: Presenilin 1, AD: Alzheimer's disease, ACVR1: Activin A receptor type 1, FOP: Fibrodysplasia ossificans progressive, COL1A2: Collagen type I alpha 2 chain, OI: Osteogenesis imperfecta, COL3A1: Collagen type 3 alpha 1, vEDS: Vascular type of the Elhers-Danlos syndrome, COL6A1: Collagen type VI alpha 1, UCMD: Ullrich congenital muscular dystrophy, KCNH2: Potassium channel voltage-gated subfamily H member 2, LQT2: Long QT syndrome type 2, KRT12: Keratin 12, MECD: Meesmann epithelial corneal dystrophy, TGFBI: TGF $\beta$-induced gene, LCDI: Lattice corneal dystrophy type I, da-SNP: disease associated-Single Nucleotide Polymorphism, iPSC: induced pluripotent stem cell, MSC: mesenchymal stem cells. 
Table 2: Single nucleotide substitutions targeted by Allele-specific RNAi in animal models

\begin{tabular}{|c|c|c|c|c|c|c|}
\hline Gene & Disease & $\begin{array}{c}\text { Targeted } \\
\text { change }\end{array}$ & Model & Comment & $\begin{array}{c}\text { Phenotype } \\
\text { reversion }\end{array}$ & Ref. \\
\hline ATXN3 & $\begin{array}{l}\text { MJD/ } \\
\text { SCA3 }\end{array}$ & da-SNP & $\begin{array}{l}\text { Lentivirus-mediated } \\
\text { expression of } \\
\text { mutant and shRNA } \\
\text { in rat brain }\end{array}$ & $\begin{array}{l}\text { Single injection in } \\
\text { striatum }\end{array}$ & $\begin{array}{c}\text { Reduce the } \\
\text { formation of } \\
\text { histological lesions } \\
8 \text { weeks post- } \\
\text { injection }\end{array}$ & [47] \\
\hline ATXN3 & $\begin{array}{l}\text { MJD/ } \\
\text { SCA3 }\end{array}$ & da-SNP & $\begin{array}{l}\text { Lentivirus-mediated } \\
\text { expression of human } \\
\text { full length mutant } \\
\text { ATXN3 and AS- } \\
\text { shRNA }\end{array}$ & $\begin{array}{c}\text { Single } \\
\text { intracerebellar } \\
\text { injection in pre } \\
\text { symptomatic mice }\end{array}$ & $\begin{array}{c}\text { Prevent } \\
\text { pathological } \\
\text { lesions, neuronal } \\
\text { loss, and motor } \\
\text { impairments } 10 \\
\text { weeks post- } \\
\text { injection }\end{array}$ & [50] \\
\hline ATXN3 & $\begin{array}{l}\text { MJD/ } \\
\text { SCA3 }\end{array}$ & da-SNP & $\begin{array}{l}\text { Lentivirus-mediated } \\
\text { expression of } \\
\text { shRNA in } \\
\text { transgenic mice } \\
\text { expressing the } \\
\text { human mutant }\end{array}$ & $\begin{array}{c}\text { Single } \\
\text { intracerebellar } \\
\text { injection in pre } \\
\text { symptomatic mice. }\end{array}$ & $\begin{array}{c}\text { Decrease in } \\
\text { histological lesions, } \\
\text { prevent neuronal } \\
\text { loss and alleviate } \\
\text { motor impairments } \\
10 \text { weeks post- } \\
\text { injection }\end{array}$ & [51] \\
\hline HTT & HD & da-SNP & $\begin{array}{l}\text { Lentivirus-mediated } \\
\text { expression of } \\
\text { shRNA in } \\
\text { transgenic mice } \\
\text { expressing full- } \\
\text { length human } \\
\text { mutant or in rat } \\
\text { expressing human } \\
\text { reporter construct }\end{array}$ & $\begin{array}{l}\text { Single injection in } \\
\text { striatum. Mice } \\
\text { injected with } \\
\text { shRNA against the } \\
\text { da-SNP or the WT } \\
\text { nucleotide }\end{array}$ & $\begin{array}{l}\text { Decrease in } \\
\text { formation of } \\
\text { histological signs in } \\
\text { rats } 8 \text { weeks post- } \\
\text { injection }\end{array}$ & [48] \\
\hline KRT6A & PC & p.N171K & $\begin{array}{l}\text { Bioluminescence } \\
\text { mouse model }\end{array}$ & $\begin{array}{l}\text { Single intradermal } \\
\text { injection of siRNA } \\
\text { and reporter } \\
\text { constructs in } \\
\text { footpad. Live } \\
\text { imaging at } 24,48 \\
\text { and } 72 \mathrm{~h} \text {. Rapid } \\
\text { down expression } \\
\text { (24h post injection) } \\
\end{array}$ & - & [31] \\
\hline KRT9 & EPPK & p.R163Q & $\begin{array}{l}\text { Bioluminescence } \\
\text { mouse model }\end{array}$ & $\begin{array}{l}\text { Single intradermal } \\
\text { injection of siRNA } \\
\text { and reporter } \\
\text { constructs in } \\
\text { footpad. Live } \\
\text { imaging at } 24 \text { hours } \\
\text { post-injection }\end{array}$ & - & [34] \\
\hline Myh6 & HCM & p.R403Q & $\begin{array}{l}\mathrm{MHC}^{403 /+} \text { knock-in } \\
\text { mice }\end{array}$ & $\begin{array}{l}\text { Single injection in } \\
\text { thoracic cavity of } \\
\text { siRNA-expressing } \\
\text { AAV9 }\end{array}$ & $\begin{array}{c}\text { No reversion } 2 \\
\text { months post- } \\
\text { injection in } \\
\text { symptomatic mice. } \\
\text { Prevent } \\
\text { cardiomyopathy in } \\
\text { presymptomatic } \\
\text { mice ( } 8 \text { weeks post- } \\
\text { injection in 1-day- } \\
\text { old mice). Arrest of }\end{array}$ & [52] \\
\hline
\end{tabular}




\begin{tabular}{|c|c|c|c|c|c|c|}
\hline & & & & & $\begin{array}{l}\text { protective effect } \\
\text { over time (at } 11 \\
\text { months of age). }\end{array}$ & \\
\hline SOD1 & ALS & p.G93A & $\begin{array}{c}\text { Transgenic mice } \\
\text { expressing the } \\
\text { mutant }\end{array}$ & $\begin{array}{c}\text { Crossing with } \\
\text { shRNA transgenic } \\
\text { mice }\end{array}$ & $\begin{array}{l}\text { Delayed onset and } \\
\text { extended survival }\end{array}$ & [49] \\
\hline SOD1 & ALS & p.G93A & $\begin{array}{l}\text { Co-injection of WT- } \\
\text {, mutant- and } \\
\text { shRNA-expressing } \\
\text { plasmids in mice }\end{array}$ & $\begin{array}{c}\text { Single systemic } \\
\text { injection in tail } \\
\text { vein. Evaluation in } \\
\text { liver } 48 \text { hours post- } \\
\text { injection } \\
\end{array}$ & - & [10] \\
\hline SOD1 & ALS & p.G93A & $\begin{array}{l}\text { Transgenic mice } \\
\text { expressing mutant }\end{array}$ & $\begin{array}{c}\text { Single systemic } \\
\text { injection in tail vein } \\
\text { of shRNA- } \\
\text { expressing AAV6 } \\
\text { in 6-week-old } \\
\text { presymptomatic } \\
\text { mice. }\end{array}$ & $\begin{array}{l}\text { No benefit for onset } \\
\text { and progression of } \\
\text { motor deficits } \\
\text { probably due to } \\
\text { insufficient } \\
\text { neuronal } \\
\text { transduction }\end{array}$ & [71] \\
\hline
\end{tabular}

Myh6: Myosin heavy chain 6, HCM: Hypertrophic cardiomyopathy, ATXN3: Ataxin 3, MJD/SCA3: MachadoJoseph disease/Spinocerebellar ataxia 3, SOD1: Superoxide dismutase 1, ALS: Amyotrophic lateral sclerosis, HTT: Huntingtin, HD: Huntington's disease, KRT9: Keratin 9, EPPK: Epidermolytic palmoplantar keratoderma, KRT6A: Keratin 6a, PC: Pachyonychia congenita, da-SNP: disease associated-Single Nucleotide Polymorphism. 
Supplementary Table 1: Overview of AS-RNAi targeting single nucleotide substitutions.

\begin{tabular}{|c|c|c|c|c|c|c|c|c|c|}
\hline Gene & Disease & $\begin{array}{c}\text { Targeted } \\
\text { change }\end{array}$ & $\begin{array}{c}\text { Silencing } \\
\text { molecule }\end{array}$ & $\begin{array}{l}\text { Mismatch } \\
\text { position }\end{array}$ & Model & $\begin{array}{c}\text { Type of } \\
\text { mismatch }\end{array}$ & Comment & $\begin{array}{c}\text { Phenotype } \\
\text { reversion }\end{array}$ & References \\
\hline ACVR1 & FOP & p.R206H & siRNA & 10,11 & $\mathrm{j}$ & py:py & & yes & {$[63]$} \\
\hline ACVR1 & FOP & $\begin{array}{l}\text { p.R206H } \\
\text { p.G356D }\end{array}$ & $\begin{array}{l}\text { siRNA } \\
\text { siRNA }\end{array}$ & $\begin{array}{c}9 / 14 \\
10 / 13\end{array}$ & $\mathrm{j}$ & $\begin{array}{c}9 \text { pu:py/14 } \\
\text { pu:pu, 10 } \\
\text { pu:py/13 } \\
\text { py:py }\end{array}$ & & yes & [64] \\
\hline APP & $\mathrm{AD}$ & p.V717I & shRNA & 9 & $\mathrm{f}$ & pu:py & & & [16] \\
\hline ATXN1 & SCA1 & da-SNP & siRNA & 10 & $\mathrm{j}$ & pu:py & & - & [65] \\
\hline ATXN3 & $\begin{array}{l}\text { MJD/ } \\
\text { SCA3 }\end{array}$ & da-SNP & siRNA/shRNA & 10 & $\mathrm{~b}$ & pu:pu & & - & {$[8]$} \\
\hline ATXN3 & $\begin{array}{l}\text { MJD/ } \\
\text { SCA3 }\end{array}$ & da-SNP & siRNA & $\begin{array}{l}7 / 8 \\
11\end{array}$ & $\mathrm{a}$ & $\begin{array}{c}7 \text { pu:pu } \\
8 \text { pu:pu } \\
11 \text { pu:pu }\end{array}$ & & yes & $\begin{array}{c}{[8]} \\
{[26]}\end{array}$ \\
\hline ATXN3 & $\begin{array}{l}\mathrm{MJD} / \\
\text { SCA3 }\end{array}$ & da-SNP & shRNA & 11 & $\mathrm{a}, \mathrm{i}$ & pu:pu & & yes & [47] \\
\hline ATXN3 & $\begin{array}{l}\text { MJD/ } \\
\text { SCA3 }\end{array}$ & da-SNP & shRNA & 11 & $\mathrm{e}$ & pu:pu & & yes & {$[51]$} \\
\hline ATXN3 & $\begin{array}{l}\text { MJD/ } \\
\text { SCA3 }\end{array}$ & da-SNP & shRNA & 11 & $\mathrm{i}$ & pu:pu & & Yes, & {$[50]$} \\
\hline ATXN3 & $\begin{array}{l}\mathrm{MJD} / \\
\mathrm{SCA} 3\end{array}$ & da-SNP & siRNA & 9,10 & $\mathrm{j}$ & pu:pu & & - & {$[65]$} \\
\hline ATXN7 & SCA7 & da-SNP & siRNA & 16 & $\mathrm{j}$ & pu:pu & & yes & [54] \\
\hline ATXN7 & SCA7 & da-SNP & shRNA/miRNA & 16 & $\mathrm{~b}$ & pu:py & & yes & [39] \\
\hline CHRNA1 & SCCMS & p.S226F & siRNA & 10 & $\mathrm{a}$ & pu:py & & - & [9] \\
\hline CHRNA1 & SCCMS & p.S226F & shRNA & 9 & $\mathrm{a}$ & pu:py & & - & [9] \\
\hline COL1A2 & $\mathrm{OI}$ & da-SNP & siRNA & 7 & $\mathrm{j}$ & pu:py & & - & [66] \\
\hline COL3A1 & vEDS & p.G252V & siRNA & 10 & $\mathrm{j}$ & pu:pu & $\begin{array}{c}\text { Syst. } \\
\text { Screen. }\end{array}$ & yes & [35] \\
\hline COL6A1 & UCMD & p.G284R & siRNA & $8,8 / 13$ & $\mathrm{j}$ & $\begin{array}{c}8 \text { pu:py, } 13 \\
\text { py:py }\end{array}$ & & yes & [43] \\
\hline GNE & Sialuria & p.R266Q & siRNA & 10 & $\mathrm{j}$ & pu:py & & yes & [67] \\
\hline HBB & SCA & p.E6V & siRNA & 10 & $a, f$ & pu:pu & & - & [57] \\
\hline HBV-P & HBV & p.M204I & siRNA & 16 & $\mathrm{f}$ & pu:pu & & - & [72] \\
\hline HTT & HD & da-SNP & siRNA & 4 & $\mathrm{j}$ & pu:pu & & - & {$[68]$} \\
\hline HTT & HD & da-SNP & siRNA & 10 & $\mathrm{j}$ & pu:py & & - & [58] \\
\hline HTT & HD & da-SNP & siRNA & 10 & $\mathrm{j}$ & pu:py & & - & [69] \\
\hline
\end{tabular}




\begin{tabular}{|c|c|c|c|c|c|c|c|c|c|}
\hline HTT & HD & da-SNP & siRNA & 16 & $\mathrm{j}$ & pu:py & & - & [65] \\
\hline HTT & HD & da-SNP & shRNA & 10,11 & $\mathrm{e}, \mathrm{j}$ & pu:py & & yes & [48] \\
\hline HTT & HD & da-SNP & siRNA & $10 / 5$ & $\mathrm{c}$ & $\begin{array}{c}10 \text { pu:py, } 5 \\
\text { py:py }\end{array}$ & & & [73] \\
\hline KCNH2 & LQT2 & p.A561T & siRNA & 13 & $\mathrm{j}$ & py:py & & yes & [46] \\
\hline K-RAS & Cancer & p.V12L & shRNA & 9 & $\mathrm{~h}$ & pu:pu & & - & [6] \\
\hline KRT12 & MECD & p.L132P & SiRNA & 9 & $\mathrm{j}$ & pu:py & & - & [70] \\
\hline KRT12 & MECD & p.L132P & siRNA & $\begin{array}{c}5,9,10,11,12 \\
14,15\end{array}$ & $\mathrm{a}, \mathrm{b}, \mathrm{c}$ & pu:py & $\begin{array}{c}\text { Syst. Screen. only } \\
\text { si9 studied in the } 3 \\
\text { models }\end{array}$ & yes & [33] \\
\hline KRT12 & MECD & p.R135T & siRNA & $5,6,8,9,13,14$ & $\mathrm{a}, \mathrm{b}, \mathrm{c}$ & pu:pu & $\begin{array}{c}\text { Syst. Screen. only } \\
\text { si5 studied in the } 3 \\
\text { models }\end{array}$ & - & [37] \\
\hline KRT5 & EBS & $\begin{array}{l}\text { p.S181P } \\
\text { p.N193K }\end{array}$ & $\begin{array}{l}\text { siRNA } \\
\text { siRNA }\end{array}$ & $\begin{array}{c}11 \\
8 \\
\end{array}$ & $\mathrm{a}$ & $\begin{array}{l}\text { pu:py } \\
\text { py:py }\end{array}$ & & $\begin{array}{l}\text { yes } \\
\text { yes }\end{array}$ & [36] \\
\hline KRT6A & $\mathrm{PC}$ & p.N171K & siRNA & $4,10,12$ & $\mathrm{~b}, \mathrm{~g}$ & py:py & $\begin{array}{c}\text { Syst. } \\
\text { Screen. }\end{array}$ & yes & [31] \\
\hline KRT9 & EPPK & $\begin{array}{l}\text { p.R163W } \\
\text { p.R163Q } \\
\text { p.M157V } \\
\text { p.M157T }\end{array}$ & $\begin{array}{l}\text { siRNA } \\
\text { siRNA } \\
\text { siRNA } \\
\text { siRNA } \\
\end{array}$ & $\begin{array}{c}3 \\
13 \\
11 \\
16 \\
\end{array}$ & $\mathrm{~b}, \mathrm{c}, \mathrm{g}$ & $\begin{array}{l}\text { pu:py } \\
\text { pu:py } \\
\text { pu:py } \\
\text { pu:py }\end{array}$ & Syst. Screen. & - & [34] \\
\hline LRRK2 & $\mathrm{PaD}$ & $\begin{array}{l}\text { p.R1441G } \\
\text { p.R1441C }\end{array}$ & $\begin{array}{l}\text { shRNA } \\
\text { shRNA }\end{array}$ & $\begin{array}{l}11 \\
11\end{array}$ & $\mathrm{c}$ & $\begin{array}{l}\text { py:py } \\
\text { pu:py }\end{array}$ & & - & [59] \\
\hline MAPT & FTDP17 & p.V337M & siRNA & $9 / 12$ & $\mathrm{~b}$ & $\begin{array}{l}9 \text { pu:py } \\
12 \text { pu:pu }\end{array}$ & & - & {$[8]$} \\
\hline MAPT & FTDP17 & p.V337M & siRNA/shRNA & 10 & $\mathrm{a}$ & pu:py & & - & [17] \\
\hline Myh6 & HCM & p.R403Q & shRNA & $16 / 20$ & $\mathrm{k}$ & $\begin{array}{l}16 \text { pu:py } \\
20 \text { py:py }\end{array}$ & $\begin{array}{c}21 \text { base-pair } \\
\text { shRNA }\end{array}$ & yes & [52] \\
\hline p53 & Cancer & p.R248W & siRNA & 9 & $\mathrm{~b}$ & pu:py & & - & [5] \\
\hline PIK3CA & Cancer & $\begin{array}{l}\text { p.E545K } \\
\text { p.H1047L }\end{array}$ & $\begin{array}{l}\text { siRNA } \\
\text { siRNA }\end{array}$ & $\begin{array}{c}10,16 \\
11\end{array}$ & $\mathrm{a}$ & $\begin{array}{l}\text { pu:py } \\
\text { pu:py }\end{array}$ & & - & [44] \\
\hline PRNP & PD & p.P102L & siRNA/shRNA & $\begin{array}{c}\mathbf{9} / 12, \mathbf{9} / 13, \mathbf{9} / 14 \\
\mathbf{9} / 17\end{array}$ & $\mathrm{a}, \mathrm{c}$ & $\begin{array}{c}9 \text { pu:pu, } 12 \\
\text { pu:pu, } 13 \\
\text { py:py, } 14 \\
\text { pu:pu, } 17 \\
\text { py:py }\end{array}$ & & - & [74] \\
\hline PRNP & PD & p.P105L & siRNA & $9, \mathbf{1 0} / 14, \mathbf{1 0} / 15$ & $\mathrm{a}, \mathrm{c}$ & $\begin{array}{c}\text { 9 and 10 } \\
\text { pu:py, } 14 \\
\text { pu:pu, } 15 \\
\text { pu:pu }\end{array}$ & & - & [74] \\
\hline
\end{tabular}




\begin{tabular}{|c|c|c|c|c|c|c|c|c|c|}
\hline PSEN1 & $\mathrm{AD}$ & p.L392V & siRNA & 10 & $\mathrm{j}$ & py:py & & yes & [32] \\
\hline PSEN1 & $\mathrm{AD}$ & p.L392V & siRNA & $8,9,10,11$ & $\mathrm{c}$ & py:py & $\begin{array}{l}\text { Syst. } \\
\text { Screen. }\end{array}$ & - & [32] \\
\hline SNCA & $\mathrm{PaD}$ & p.A30P & shRNA & $10,13,14$ & $\mathrm{~b}, \mathrm{c}$ & pu:pu & & - & {$[40]$} \\
\hline SNCA & $\mathrm{PaD}$ & p.A53T & siRNA & 9 & $\mathrm{a}$ & pu:py & $\begin{array}{l}\text { 21-base-pair } \\
\text { siRNA }\end{array}$ & - & [41] \\
\hline SOD1 & ALS & p.G85R & siRNA & 10 & $\mathrm{a}$ & pu:pu & & - & [10] \\
\hline SOD1 & ALS & p.G85R & siRNA & $\begin{array}{c}5,9,10,12 \\
13,14,16\end{array}$ & $\mathrm{c}$ & pu:pu & $\begin{array}{c}\text { Syst. } \\
\text { Screen. }\end{array}$ & - & [30] \\
\hline SOD1 & ALS & p.G93A & siRNA/shRNA & 10,16 & $\mathrm{a}, \mathrm{d}$ & pu:pu & & - & {$[10,75]$} \\
\hline SOD1 & ALS & p.G93A & shRNA & 11 & $\mathrm{e}$ & pu:pu & $\begin{array}{c}\text { Crossing with } \\
\text { shRNA transgenic } \\
\text { mice }\end{array}$ & yes & [49] \\
\hline SOD1 & ALS & p.G93A & shRNA & 9 & $\mathrm{e}$ & pu:pu & & No benefit & [71] \\
\hline TARDBP & ALS & p.M337V & & 9 & $\mathrm{j}$ & pu:py & & - & [42] \\
\hline TGFBI & LCDI & p.R124C & siRNA & 14 & $\mathrm{j}$ & pu:py & & - & [38] \\
\hline TGFBI & LCDI & p.R124C & siRNA & $8,14,16$ & $\mathrm{a}, \mathrm{c}$ & pu:py & Syst. Screen. & yes & [38] \\
\hline TTR & FAP & p.V30M & siRNA & 10 & $a, b$ & pu:py & & & [76] \\
\hline
\end{tabular}

Model: a: cells transfected with WT or mutated transcripts, b: co-transfection of WT and mutants in vitro, c: cell-free assay or reporter assay in vitro, d: co-transfection of WT and mutants in vivo, e: Transgenic mice expressing WT or mutated transcripts, f: stably transfected cells with mutated transcripts, g: reporter assay in vivo in mice, h: cell lines endogenously expressing WT or mutant, i: overexpression of mutated transcript in vivo, j: patient-derived cells, k: knock-in mouse model. Mismatch positions are indicated relative to the most 5' nucleotide of the antisense strand. In case of double mismatch, the position of the mutated nucleotide is indicated in bold. Syst. Screen: Systematic screening; i.e. the 19 possible siRNA with the mutated nucleotide at each position were tested. pu: purine base, py: pyrimidine base, da-SNP: disease associated-Single Nucleotide Polymorphism, SOD1: Superoxide dismutase 1, ALS: Amyotrophic lateral sclerosis, APP: Amyloid precursor protein, AD: Alzheimer's disease, ATXN3: Ataxin 3, MJD/SCA3: Machado-Joseph disease/Spinocerebellar ataxia 3, GNE: UDP-N-acetylglucosamine 2-epimerase/N-acetylmannosamine kinase, HTT: Huntingtin, HD: Huntington's disease, ATXN1: Ataxin 1, SCA1: Spinocerebellar ataxia 1, ATXN7: Ataxin 7, SCA7: Spinocerebellar ataxia 7, TARDBP: TAR-DNA Binding protein (TDB43), PSEN1: Presenilin 1, ACVR1: Activin A receptor type 1, FOP: Fibrodysplasia ossificans progressive, COL1A2: Collagen type I alpha 2 chain, OI: Osteogenesis imperfecta, COL3A1: Collagen type 3 alpha 1, vEDS: Vascular type of the Elhers-Danlos syndrome, COL6A1: Collagen type VI alpha 1, UCMD: Ullrich congenital muscular dystrophy, KCNH2: Potassium channel voltage-gated subfamily H member 2, LQT2: Long QT syndrome type 2, KRT12: Keratin 12, MECD: Meesmann epithelial corneal dystrophy, TGFBI: TGFß-induced gene, LCDI: Lattice corneal dystrophy type I, Myh6: Myosin heavy chain 6, HCM: Hypertrophic cardiomyopathy, MAPT: Microtubule-associated protein Tau, FTDP17: Frontotemporal dementia with parkinsonism linked to chromosome 17, CHRNA1: Acetylcholine receptor alpha subunit, SCCMS: Slow channel congenital myasthenic syndrome, TTR: Transthyretin, FAP: Familial amyloidotic polyneuropathy, HBB: Hemoglobin beta locus, SCA: Sickle cell anemia, KRT6A: Keratin 6a, PC: Pachyonychia congenita, KRT5: Keratin 5, EBS: Epidermolysis bullosa simplex, PRNP: Prion protein, PD: Prion diseases, PIK3CA: Phosphoinositide-3-kinase catalytic alpha polypeptide, HBV-P: HBV polymerase gene, HBV: Hepatitis B Virus infection, PSEN1: Presenilin 1, AD: Alzheimer's disease, LRRK2: Leucin-rich repeat kinase 2, SNCA: Alpha-synuclein, PaD: Parkinson's disease, KRT12: Keratin 12, KRT9: Keratin 9, EPPK: Epidermolytic palmoplantar keratoderma. 
Supplementary Table 2: AS-RNAi targeting multiple nucleotide changes responsible for dominant diseases.

\begin{tabular}{|c|c|c|c|c|c|c|}
\hline Gene & Disease & $\begin{array}{c}\text { Targeted } \\
\text { change }\end{array}$ & $\begin{array}{l}\text { Silencing } \\
\text { molecule }\end{array}$ & Model & $\begin{array}{c}\text { Phenotype } \\
\text { reversion }\end{array}$ & Reference \\
\hline APP & $\mathrm{AD}$ & $\begin{array}{l}\text { 2-nucleotide } \\
\text { substitution }\end{array}$ & siRNA & $\mathrm{c}$ & - & [15] \\
\hline APP & $\mathrm{AD}$ & $\begin{array}{l}\text { 2-nucleotide } \\
\text { substitution }\end{array}$ & shRNA & $\mathrm{a}$ & - & [16] \\
\hline APP & $\mathrm{AD}$ & $\begin{array}{l}\text { 2-nucleotide } \\
\text { substitution }\end{array}$ & siRNA/shRNA & $\mathrm{a}$ & - & [17] \\
\hline APP & $\mathrm{AD}$ & $\begin{array}{l}\text { 2-nucleotide } \\
\text { substitution }\end{array}$ & shRNA & $\mathrm{e}$ & yes & {$[21]$} \\
\hline ATXN3 & MJD & CAG repeat & siRNA & $\mathrm{a}$ & - & [26] \\
\hline ATXN3 & MJD & CAG repeat & siRNA & $\mathrm{j}$ & - & [29] \\
\hline CACNA1A & SCA6 & $\begin{array}{l}\text { Partial exon } \\
\text { inclusion }\end{array}$ & siRNA/shRNA & $\mathrm{a}, \mathrm{c}$ & - & {$[25]$} \\
\hline COL1A1 & $\mathrm{OI}$ & $\begin{array}{l}\text { 2-nucleotide } \\
\text { substitution }\end{array}$ & siRNA/shRNA & $\mathrm{a}, \mathrm{h}$ & - & {$[18]$} \\
\hline COL6A3 & UCMD & $\begin{array}{c}\text { Exon } \\
\text { exclusion }\end{array}$ & siRNA & $\mathrm{j}$ & yes & [24] \\
\hline COL7A1 & DDEB & $\begin{array}{c}\text { Exon } \\
\text { exclusion }\end{array}$ & siRNA & $\mathrm{c}, \mathrm{j}$ & - & [23] \\
\hline EGFR & Cancer & $\begin{array}{c}\text { Exon } \\
\text { exclusion }\end{array}$ & siRNA & $\mathrm{c}, \mathrm{i}, \mathrm{j}$ & yes & [14] \\
\hline EGFR & Astrocytoma & $\begin{array}{c}\text { Exon } \\
\text { exclusion }\end{array}$ & siRNA & $\mathrm{a}$ & yes & {$[22]$} \\
\hline FGFR2 & CS & $\begin{array}{l}\text { 2-nucleotide } \\
\text { substitution }\end{array}$ & shRNA & $\mathrm{k}$ & yes & [20] \\
\hline HTT & HD & $\begin{array}{l}\text { 3-nucleotide } \\
\text { deletion }\end{array}$ & siRNA & $\mathrm{b}, \mathrm{j}$ & yes & [13] \\
\hline HTT & HD & CAG repeat & RNA duplex & $\mathrm{j}$ & - & [27] \\
\hline HTT & HD & CAG repeat & RNA duplex & $\mathrm{j}$ & - & [28] \\
\hline RYR1 & $\mathrm{MH}$ & $\begin{array}{l}\text { 3-nucleotide } \\
\text { substitution }\end{array}$ & siRNA & $\mathrm{k}$ & yes & [19] \\
\hline RYR1 & CCD & $\begin{array}{l}\text { 2-nucleotide } \\
\text { substitution }\end{array}$ & siRNA & $\mathrm{k}$ & yes & [19] \\
\hline
\end{tabular}




\begin{tabular}{|c|c|c|c|c|c|c|}
\hline TOR1A & DYT1 & $\begin{array}{c}\text { 3-nucleotide } \\
\text { deletion }\end{array}$ & siRNA & a,b & - & {$[7]$} \\
\hline TOR1A & DYT1 & $\begin{array}{c}\text { 3-nucleotide } \\
\text { deletion }\end{array}$ & shRNA & $\mathrm{a}, \mathrm{b}$ & yes & {$[12]$} \\
\hline
\end{tabular}

Model: a: cells transfected with WT or mutated transcripts, b: co-transfection of WT and mutants in vitro, c: cell-free assay or reporter assay in vitro, e: Transgenic mice expressing WT or mutated transcripts, h: cell lines endogenously expressing WT or mutant, i: overexpression of mutated transcript in vivo, j: patient-derived cells, k: knock-in mouse model. TOR1A: Torsin A, DYT1: Dystonia. HTT: Huntingtin, HD: Huntington's disease, EGFR: Epidermal growth factor receptor, APP: Amyloid precursor protein, AD: Alzheimer's disease, COL1A1: $\alpha 1$ chain of type I collagen, OI: Osteogenesis imperfecta, RYR1: Ryanodyne receptor type 1, MH: Malignant hyperthermia, CCD: Central core disease, FGFR2: Fibroblast growth factor receptor 2, CS: Craniosynostosis, COL7A1: $\alpha 1$ chain of type VII collagen, DDEB: Dominant dystrophic epidermolys bullosa, COL6A3: $\alpha 3$ chain of type VI collagen, UCMD: Ullrich congenital muscular dystrophy, CACNA1A: Cav2.1 voltage-gated calcium channel, SCA6: Spinocerebellar ataxia type 6, ATXN3: Ataxin 3, MJD: Machado-Joseph disease. 